\title{
Indispensable for Preventıve Dentistry: Fissure Sealants
}

\author{
Arife Kaptan* and Elif Tekin \\ Cumhuriyet University, Turkey
}

*Corresponding author: Arife KAPTAN, Cumhuriyet University, Department of Pediatric Dentistry, Turkey.

Received Date: February 20, 2019

Published Date: March 14, 2019

\begin{abstract}
Fissure Sealants are materials that are applied to the pits and fissures in tooth in preventing tooth cavities. The success of the fissure sealants depends on degree of binding with tooth surface and isolating capacity the pit and fissures from the mouth environment. The purpose of this review is to investigate the reasons for applying fissure sealants, application technique and types of fissure sealants.
\end{abstract}

Keywords: Fissure sealants; Glass carbomer; Pediatric dentistry

\section{Introduction}

In recent years, the greatest interest of modern dentistry; it focuses on reducing the risk of caries, preventive practices, and non-invasive conservative techniques where dental structures are protected as much as possible [1]. In previous caries research, occlusal surfaces have been found to susceptible to caries due to pits and fissures resulting from anatomical structures. Especially in children and young people, caries are most commonly seen in fissures [2]. The most effective method to prevent caries from these areas is the application of pit and fissure sealants. Pit and fissure sealants, one of the basic methods of preventive dentistry, are increasingly used in developed countries with the purpose of prevent occusal surface caries [3]. Fissure sealants are prevent plaque microflora and food-borne debris from accumulation in caries-susceptible pits and fissures. In addition, it reduces the effect of acid formed by the bacteria causing caries and remineralises the new lesions of the caries [4].

The contents of pit and fissure sealants, such as other restoration material used in dentistry, have been further developed over time. Fissure sealants with glass ionomer cement (GIC) and bisphenol A-glycidyl methacrylate (Bis-GMA) which is the basis of composite restoration materials, have been recently most preferred in clinical use [5,6]. However, the content of pit and fissure sealants has changed in parallel with the recent developments of both composite resins and glass ionomer cements [7]. Bis-GMA is formed by the reaction of an organic compound called Bisphenol-A and glycidyl methacrylate at a $1 / 2$ molecule ratio. Fissure sealants contain $1 / 3$ methyl methacrylate (MMA) monomer, which is more fluid than composite resins. This material exhibits good surface wettability and improved physical properties and suitable fluidity due to its low viscosity. The major disadvantage of resin-based fissure sealants is polymerization shrinkage, which permits bacterial penetration and leads to the formation of gaps leading to failure of restoration [8].

Glass ionomer cement-based fissure sealants are bond chemically to calcified tissues such as enamel and dentin. Their biocompatibility is good. Due to its fluoride content, it has anticarogenic properties [9]. Since the GICs can be bonded with chemical adhesion to enamel and dentin without the need for acidification of the enamel, thus application time is shortened and it gives a great advantage especially for young children. However, the inadequate mechanical and physical properties of GICs such as abrasion resistance, durability, retention and color stability as well as the high solubility in the oral environment limits their clinical success [10]. Recently, glass ionomer-based restorative material, glass carbomer, has been introduced. Glass carbomer is a new commercially available glass ionomer used as restorative filler material and fissure sealant designed to provide remineralization in the oral environment. The calcium fluoroapatite nanocrystals contained in the glass carbomers act as catalysts to remineralize the tooth and initiate fluorapatite formation [11]. The liquid of glass carbomer is polyacrylic acid. Similar to high viscosity GICs, the addition of nano-filling particles to glass carbomer cement can increase the pressure resistance and wear resistance [12]. 
Glass carbomers include fluoride aluminum-silicate glass, nano-fluoride /hydroxyapatite, polyacrylic acid [12,13]. In addition, they do not include resin, monomer, metal and Bisphenol-A where their possible toxic effects are discussed [13]. Glass carbomers are chemically cured, such as GICs, but heat application is recommended during the curing process $[13,14]$. It is recommended that heat application be carried out using an LED curing light (recommended wavelength $1400 \mathrm{~mW} / \mathrm{cm} 2$ ) with 60$90 \mathrm{sec}$ [13]. Heat application; shortens the curing time, increases the adhesion to the dental tissue and the mechanical properties of the material. The major important evaluation criterias of success in the fissure sealants are the micromechanical connection and long-term retention of the material to the enamel surface. This retention depends on isolation, viscosity of the material, method used in preparation of the enamel surface and usage of the adhesive system [15]. Microleakage is defined as bacterial, liquid, molecule and ion transition that cannot be clinically detected between cavity margins and applied restorative material. If the applied material is not resistant to microleakage, the success of the fissure sealant is adversely affected and caries formation may be observed [16].

Fissure sealants are applied in two ways; invasive technique and non-invasive technique. "Invasive technique" is perfomed by bur preparation in pit and fissures for elimination of organic material, plaque, and a very thin layer of prismless enamel by the widening and deepening of pits and fissures. This method allows to acid and sealant penetration into deeper portions of fissures and increases the surface area [17]. In some studies, invasive fissure sealant application has superior results in terms of microleakage compared to untreated fissures and air-abrasive tooth surfaces $[17,18]$. On the other hand, in a study claiming otherwise, the increase in sealant volume required to fill the expanded fissures is reported to increase the stress of polymerization shrinkage [19]. As a result, this condition decreases sealant retention compared to only acid etching fissures. Besides, many authors agree with the idea that the invasive approach decrease the risk of microleakage, rises sealant penetration and eliminates organic materials and the layer of prismless enamel [20].

The use of invasive technique prior to the sealant application increases the retention of the sealant as well as providing dentists with more controlled operate in pits and fissures, which caries are difficult to diagnose. According to Pope et al., [21] invasive technique should be used in case of suspicion in caries diagnosis. Making choice between invasive and non-invasive techniques is still a controversial issue [20]. Regarding the invasive technique, it has been reported that retention is increased and the risk of microleakage decreases after mechanical preparation of fissures [21]. However, sealants applied by non-invasive techniques, have been reported to be highly effective in preventing pit and fissure caries, and their efficacy and retention have been demonstrated in many clinical studies [22]. Moreover, purposeful removal just to widen the base of a fissure in a sound tooth is an invasive technique, which disrupts the balance of the fissure system and exposes a child unnecessarily to the use of a handpiece or air abrasion. It is also a disadvantage of the method that teeth need to be restored over and over again [23].

\section{Conclusion}

At the present time, especially in childhood, the necessary oral hygiene instruction and preventive applications are made and it is aimed to minimize the formation of caries both in childhood and adulthood stage. The most successful method for protection of occlusal surfaces from caries is pit and fissure sealants.

\section{Acknowledgement}

None.

\section{Conflicts of Interest}

The authors declare no potential conflicts of interest with respect to the authorship and/or publication of this article.

\section{References}

1. Newbrun E (1992) Preventing dental caries: current and prospective strategies. J Am Dent Assoc 123(5): 68-73.

2. Wyne AH (2008) Caries prevalence, severity, and pattern in preschool children. J Contemp Dent Pract 9(3): 24-31.

3. Manton DJ, Messer LB (1995) Pit and fissure sealants: another major cornerstone in preventive dentistry. Aust Dent J 40(1): 22-29.

4. Waggoner WF, Siegal M (1996) Pit and fissure sealant application: updating the technique. J Am Dent Assoc 127(3): 351-361.

5. Cohen L, Sheiham A (1988) The use of pit and fissure sealants in the General Dental Service in Great Britain and Northern Ireland. Br Dent J 165(2): 50-53.

6. McLean JW, Wilson AD (1974) Fissure sealing and filling with an adhesive glass-ionomer cement. Br Dent J 136(7): 269-276.

7. Gungor HC, Altay N, Alpar R (2004) Clinical evaluation of a polyacidmodified resin composite-based fissure sealant: two-year results. Oper Dent 29(3): 254-260.

8. Hicks J FC (2009) Pit ve fissür örtücüler ve konservatif adeziv restorasyonlar: Bilimsel ve klinik temeller 1999. In: Çocuk Diş Hekimliği: Bebeklikten Ergenliğe EPJ, Casamassimo PS, McTigue DJ, Nowak AJ. Çeviri Ed. Tortop T, Tulunoğlu Ö. 4. Baskı. Ankara: Atlas Kitapçıllk; 520576.

9. Wilson AD, Kent BE (1972) A new translucent cement for dentistry. The glass ionomer cement. Br Dent J 132(4):133-135.

10. Antonson SA, Wanuck J, Antonson DE (2006) Surface protection for newly erupting first molars. Compend Contin Educ Dent 27(1): 46-52.

11. Zainuddin N, Karpukhina N, Law RV, Hill RG (2012) Characterisation of a remineralising Glass Carbomer(R) ionomer cement by MAS-NMR spectroscopy. Dent Mater 28(10): 1051-1058.

12. Cehreli SB, Tirali RE, Yalcinkaya Z, Cehreli ZC (2013) Microleakage of newly developed glass carbomer cement in primary teeth. Eur J Dent 7(1): 15-21.

13. GCP GmbH Gcp glass fill product manual.

14. Menne Happ U, Ilie N (2013) Effect of gloss and heat on the mechanical behaviour of a glass carbomer cement. J Dent 41(3): 223-230.

15. Ulusu T, Odabas ME, Tuzuner T, Baygin O, Sillelioglu H, et al. (2012) The success rates of a glass ionomer cement and a resin-based fissure sealant placed by fifth-year undergraduate dental students. Eur Arch Paediatr Dent 13(2): 94-97.

16. Gungor HC, Turgut MD, Attar N, Altay N (2003) Microleakage evaluation of a flowable polyacid-modified resin composite used as fissure sealant on air-abraded permanent teeth. Oper Dent 28(3): 267-273.

17. Hatibovic-Kofman S, Wright GZ, Braverman I (1998) Microleakage of sealants after conventional, bur, and air-abrasion preparation of pits and fissures. Pediatr Dent 20(3): 173-176. 
18. Wright GZ, Hatibovic-Kofman S, Millenaar DW, Braverman I (1999) The safety and efficacy of treatment with air abrasion technology. Int J Paediatr Dent 9(2): 133-140.

19. Davidson CL, Feilzer AJ (1997) Polymerization shrinkage and polymerization shrinkage stress in polymer-based restoratives. J Dent 25(6): 435-440.

20. Salama FS, Al Hammad NS (2002) Marginal seal of sealant and compomer materials with and without enameloplasty. International journal of paediatric dentistry / the British Paedodontic Society [and] the International Association of Dentistry for Children 12(1): 39-46.
21. Pope BD, Jr., Garcia-Godoy F, Summitt JB, Chan DD (1996) Effectiveness of occlusal fissure cleansing methods and sealant micromorphology. ASDC J Dent Child 63(3): 175-180.

22. Ripa LW (1993) Sealants revisted: an update of the effectiveness of pitand-fissure sealants. Caries Res 1: 77-82.

23. Welbury R, Raadal M, Lygidakis NA (2004) EAPD guidelines for the use of pit and fissure sealants. Eur J Paediatr Dent 5(3): 179-184. 